\title{
Noir sans frontiers: reflections on the transnational flaneur-as-detective
}

\begin{abstract}
As Walter Benjamin astutely observes in the Arcades Project and elsewhere, one of the earliest incarnations of the flaneur is to be found in the figure of the urban detective as first conceived in the writings of Edgar Allen Poe and Eugene Sue. In this paper I reflect upon this identification and briefly consider the multiple incarnations of the flaneur and the significance of transnational flanerie in the contemporary cultural and political context. Taking the Danish-Swedish-German neo-noir television series The Bridge (Bron / Broen) $[2011,2013,2015]$ as an exemplary contemporary instance of the 'transnational urban detective,' I consider three kinds of transationalism:

a) how noir itself constitutes a transitional genre, migrating across borders;

b) how media products / formats can be embedded, dis-embedded and re-embedded in new and different transnational contexts as part of the global culture industry.

c) how noir detectives weave back and forth across and between cities in neighbouring countries as part of their investigations.
\end{abstract}

I conclude with reflections on how the bridge itself - the very symbol of transnationalism forms a marginal and liminal site, a non place (Marc Augé's non lieu) and threshold or inbetween space (Siegfried Kracauer's Zwischenräume), and in so doing provides the transitional flaneur-as-detective not so much with a home but a haunt, a locus of habitual return and inescapable melancholy.

Keywords: flaneur, detective, transnationalism, noir. 
In Einbahnstrasse under the title 'Paperweight' Walter Benjamin wryly suggests how astonished, and indeed triumphant, the pharaohs of ancient Egypt would have been to discover one of their hieroglyph-adorned columns, the Obelisk, standing tall amidst the incessantly circulating traffic of present-day Paris, transplanted to be sure, but still very much at the centre of things, in the heart of what was for him the nineteenth-century capital of capital. ${ }^{1}$ Then again, a culture so preoccupied with the afterlife of humans, animals and artefacts may not have been so surprised: as the great pyramids and other elaborate burial complexes attest, this was a civilization in which the most ambitious and ostentatious architecture imaginable was oriented to the posthumous and to posterity. But the pharaohs' monument is vainglorious: as Benjamin points out, the Obelisk in the Place de la Concorde receives scant attention today, and no-one bothers to decipher its pictorial script. It stands irrelevant and illegible, an anachronism.

Architecture outlasts the builders; an object the artisan; an artwork the artist; and a text its author. Benjamin was all too aware of this notion of the after-life [Nachleben] or after-history [Nachgeschichte] of things and indeed made the study of its manifold forms and fragments his own: the ruin, the obsolete, the outmoded, the unfashionable, the vestige, the trash, the trace; the ghost. And he too, like the pharaoh, would probably be a little - but not a lot astonished to find that today, seventy-five years after his own tragic death, scholars around the world continue to discuss one of his most inscrutable metaphorical / allegorical figures: the flaneur, or more precisely the transnational flaneur (with contributions from scholars from Korea, France and Britain, this very volume of Sociétés itself is testimony to the flaneur as transnational phenomenon). Never a triumphalist, though, Benjamin would surely have allowed himself a little smile: for we are very much paying attention, trying to read this figure precisely because the flaneur remains so elusive and enigmatic. "It does not permit itself to be read [Es lässt sich nicht lessen]" - Edgar Allen Poe's final verdict on the countenance of the 'man of the crowd' applies to both ancient Obelisk and the face of the flaneur though their contemporary fates are very different; for the former, it ensures futility and forlornness; for the latter, it is the very source of an enduring fascination. ${ }^{2}$

\footnotetext{
${ }^{1}$ W. Benjamin, Selected Writings Vol. 1: 1913-26, Harvard UP, Cambridge, MA, 1996, p. 462.
}

${ }^{2}$ E. A. Poe, The Portable Edgar Allan Poe, Penguin Classics, London, 2006, p. 229. 
My point is this: How curious it is that we continue to discuss the concept of the flaneur, a figure who, for Benjamin drawing on Charles Baudelaire, relished sauntering on the Parisian boulevards and through the arcades for only a few decades in the middle of the nineteenth century before being elbowed off the pavement and swallowed up by the burgeoning metropolitan crowd, and who enjoyed a brief albeit memorable return or reincarnation in 1920s Berlin in the reflections of his close friend and collaborator Franz Hessel! ${ }^{3}$ We should ask ourselves: why has this eccentric, short-lived figure - metropolitan, male, middle-class, white, heterosexual, European, scopophilic, chauvinist, pretentious, politically myopic, a snob, a dandy, an aesthete, a peacock, a fop, a fraud, an idler, an irrelevance, a tortoisewalking absurdity, "call him what you will” Baudelaire observes, ${ }^{4}$ invitingly - why has he so captured our imagination? And, most significantly, how has this figure and its many guises and disguises undergone processes of transformation, translation, transgendering, transplantation and transnationalization such that, unlike the oversized Egyptian 'paperweight', it still somehow speaks to and resonates with us today? Why do we continue to circle around, time and again, this puzzling figure from the past as if caught in its centripetal pull? The flaneur is an anachronism, to be sure, but one that still happily haunts us.

\section{II}

In the words of the song, "everything goes back to the beginning .."

It is nearly a quarter of a century since I first published an article (indeed it was my first ever publication!) on the theme of the flaneur as 'heroic pedestrian, pedestrian hero', and more than twenty years since, in another essay, I attempted to trace the remarkable persistence and continuing pertinence of this most curious figure - what I termed the 'afterlife of an allegory' - in a variety of new incarnations and as a metaphor or trope in contemporary cultural thought. The flaneur, and flaneuse, I suggested, had become a point of reference for a whole host of only loosely connected experiences and practices involving movement in urban spaces and between cities, in cyberspace and between websites: tourism, window shopping,

\footnotetext{
${ }^{3}$ See for example F. Hessel, Walking in Berlin. A Flaneur in the Capital, Scribe Editions, Melbourne / London, 2016.

${ }^{4}$ C. Baudelaire, The Painter of Modern Life and Other Essays, Da Capo Press, New York NY, 1964/1986, p. 4.
} 
prostitution, pilgrimage, migration, taxi-driving, couriering, velo-couriering, velo-taxiing, truck driving, (citizen-)journalism, charity work, au pair work and babysitting, browsing, hacking, computer gaming, parkour and free-running, skateboarding, internet surfing, channel hopping, bar hopping, club-scene cruising, hitch-hiking, jogging, loitering, stalking. The flaneur was now to be found strolling on two legs, pedalling on two wheels, driving on four wheels, sitting on the sofa, glued to the screen, perched at the desk, at the counter, at the bar, in the airport, on the lookout, on the hop. And why should the flaneur be confined to cities?: is flanerie impossible in rural setting and landscapes?: what of rambling, hiking, hill-walking, trekking, orienteering, BMXing, off-piste skiing and snowboarding? With all these aliases and avatars, the flaneur seemed in danger of vanishing into a new crowd of possible identities and countenances. Maybe we are all flaneurs / flaneuses now; flaneurs/se R us. Perhaps, though that is hardly helpful. Perhaps we should go back briefly to the beginning, back to Baudelaire and his seminal account of the 'The Painter of Modern Life' (1863). Here, in a key passage Baudelaire writes:

"The crowd is his element, as the air is that of birds and water of fishes. His passion and his profession are to become one flesh with the crowd. For the perfect flaneur, for the passionate spectator, it is an immense joy to set up house in the midst of the multitude, amid the ebb and flow of movement, in the midst of the fugitive and the infinite. To be away from home and yet to feel oneself everywhere at home; to see the world to be at the centre of the world, and yet to remain hidden from the world - such are a few of the slightest pleasures of those independent, passionate, impartial natures which the tongue can but clumsily define. The spectator is a prince who everywhere rejoices in his incognito. ... Thus the lover of universal life enters into the crowd as though it were an immense reservoir of electrical energy. ... He is an 'I' with an insatiable appetite for the 'non-I', at every instant rendering and explain it in pictures more living than life itself, which is always unstable and fugitive". 5

I suggest three points emerge from this.

Firstly, what is decisive about the flaneur is that the figure combines movement through urban space with "passionate" spectatorship and visual representation: the flaneur is always and everywhere a sightseer though not in the conventional sense. Motion and vision mean that the setting is always both moved through and subject to observation and scrutiny: flanerie takes in its surrounds en passant or en traversant. The flaneur is an attentive and

\footnotetext{
${ }^{5}$ Ibid pp. 9-10.
} 
acute eye on the go: what is seen, the urban environment, is transformed into an object of critical scrutiny and aesthetic appreciation. The quotidian becomes remarkable, the everyday extraordinary: the flaneur presages the film camera in its rediscovery of the Benjaminian 'optical unconscious'. The city becomes a cityscape, a spectacle, a work of art.

Secondly, the flaneur is not just an embodiment of vision, but also an envisioning of a model of and for the privileged pedestrian, a "prince" of the pavement. This "perfect flaneur" steps out as a utopian figure in a number of ways:

a) at liberty to move freely, unperturbed and unmolested, through the public spaces of the city thronged with crowds of strangers, without constraint, resistance or trepidation; the flaneur assumes an uncontested right to be out and about on the town and an entitlement to proper respect and due deference (such rights and claims have been anything but self-evident for the flaneuese of course);

b) at leisure to watch others while remaining unobserved oneself, seemingly invisible to others as they hurry about their business, the flaneur luxuriates in a vantage-point of power and prestige. There is something of the perambulating panopticon about this invisible, incognito spectator.

c) at home amid the agitated, anonymous crowd, the flaneur finds ease and comfort among the unknown and unknowable multitude of strangers. The flaneur finds inviting and welcoming precisely that which most citizens experience as disquieting, disorientating, distasteful: the "non-I". There is an openness to and embrace of otherness here in which anxiety becomes excitement, the hostile hospitable, the unhomely [unheimlich] homely [hiemlich] At home everywhere and anywhere, the flaneur may be an eccentric and enigmatic figure, but s/he is not an uncanny one. Indeed, one might say, if such a word existed, the flaneur is a figure of "de-uncannification" or "re-cannification" of the modern metropolis. Indeed, the flaneur, as Baudelaire points out here, makes and remakes not just the city but "the world". In this sense, the flaneur has always been a cosmopolitan, a figure of the transnational.

Why is the flaneur so enticing for us today?: perhaps in part at least because, in our terrified terrorized times of securitization and militarization, of petty nationalism and populist xenophobia, of the architecture of exclusion (walls, barriers and towers), and of subjection to para-military policing, to cyber-surveillance, suspicion, and sanction, this is a 'wish-image' 
of emancipation and internationalism, a dream-figure of freedom: to move nonchalantly and casually as, when and where one wishes; to saunter across boundaries and trespass thresholds, to traverse borders and frontiers without let or hindrance, blithely disregarding, disrespecting any and all such demarcations and designations; to see and yet remains unseen, surreptitiously side-stepping surveillance, screening and scrutiny; to delight in encounters with difference and otherness. Let us not forget that flanerie was - and must be - sans frontiers.

Indeed, one might venture to say that the transnational flaneur has perhaps never been more relevant: as a figure of the free movement of the person, of people, at a moment when the free movement of goods and services takes a priority. And not just 'priority': I live in a country where the elected politicians are trying to solve the riddle of allowing commodities to move unmolested across international boundaries while at the same time preventing human beings people from doing the same. They term this 'having one's cake and eating it'. As Benjamin informs us, the "last incarnation" of the flaneur was as a circulating advertisement, as "sandwich-man" gesture towards freedom, an intimation and anticipation that the commodity would not merely be fetishized, but would be granted freedoms and privileges in exact proportion to their loss by humans. To adopt the guise of a walking commodity was a ruse to enjoy the rights now only artefacts are now permitted. Welcome to twenty-first century Britain: open for business, closed to people!

Thirdly, as attentive observer of the milling metropolitan crowd, there are the rudiments here of the particular incarnation of the flaneur that I wish to discuss here: this is, then, one of the first, if not the first guise or disguise adopted by the flaneur: the figure of the detective. What are these rudiments? I suggest here that there are six: a) detective as the acute and astute observer of the city and it inhabitants who sees through the everyday to disclose what lies below the surface. Detective as critical urban reader and interpreter who fundamentally mistrusts the appearances of things, who shows us that the everyday world is not quite what is seems, that is another layer of reality to be revealed and unfolded (this is the key to

\footnotetext{
${ }^{6}$ W. Benjamin, The Arcades Project, Harvard UP, Cambridge, MA, 1999, p. 451.
} 
detective and espionage fiction as Luc Boltanski ${ }^{7}$ has recently argued); detective as archaeologist of the city, as the collector, compositor and interpreter of fragments of quotidian urban life; c) as a figure of digression and seduction, the detective is continually circling the city in the hunt for clues and for the killer; this also involves mistakes and misidentifications, misinterpretations (the detective stories is full of deliberate misdirection on the part of the writer, so-called 'red herrings'); d) detective as a brooder over the puzzle s/he has brought together (this is the 'crime board' set up in the police station in which the fragments are collected and set out in relation to one another (the detective is confronted by a mystery which must be solved and s/he is reduced to a state of intense melancholy by picture puzzle pieces that do not fit together, that do not cohere, by the illegible hieroglyph); e) the detective is the one who shows through the construction of a montage of the crime itself on the crime board (detective reconstructs and shows the truth of the past from the pieces s/he has assembled); the detective finally turns into the narrator, the storyteller who is able to recount events, able to render communicable that which began as in comprehensible, as incommunicable, the detective is the model historian as storyteller for hat $\mathrm{s} / \mathrm{he}$ reconstructs is the storyboard of the story itself. The detective tells his / her own tale - hence, the common device of the voice over - because s/he is the author; detective story is the tale of the process by which the detective retrospectively comes to reconstruct / recreate the story from its pieces. Detective fiction is always metafiction in that sense: the story of the recovery / the (re)writing of a story.

The detective is the urban observer par excellence, the great reader of the cityscape who is acutely attentive to the physiognomies of its inhabitants and the traces, the clues, they leave behind.

Among the numerous correspondences Benjamin posits between these two figures in Convolute M of the Arcades Project, one finds the following unequivocal identification:

"Preformed in the figure of the flaneur is that of the detective. The flaneur required a social legitimation of his habitus. It suited him very well to see his indolence as a plausible front, behind which, in reality, hides the riveted attention of an observer who will not let the unsuspecting malefactor out of his sight." "8 (1999: 442).

\footnotetext{
${ }^{7}$ See L. Boltanski, Mysteries and Conspiracies. Detective Stories, Spy Novels and the Making of Modern Society, Polity Press, Cambridge, UK, 2014.

${ }^{8}$ W. Benjamin, The Arcades Project, Harvard UP, Cambridge MA, 1999, p. 442.
} 
All this returns us to 'The Man of the Crowd'.

\section{III}

Baudelaire, and Benjamin in turn, recognizes Poe's eerie tale from 1840 as one of the defining literary incarnation of the flaneur, though exact identifications are subject to dispute: is the daemonic 'man of the crowd' himself, prowling the nocturnal streets of early Victorian London in perpetual search of asylum amid the last vestiges of the daytime urban crowd, a vision of the flaneur or, more likely, is it his pursuant, the narrator who follows him from a safe distance, lured ever onwards by a compelling fascination which remains ultimately unsatisfied as dawn breaks and the spell is finally broken? The flaneur as hunter or as hunted, as criminal-detective or innocent victim and stalker - however this duality is configured, this curious story provides Benjamin with what he famously terms an "something like an X-ray of a detective story," 9 an outline in which its skeletal structure is clearly evident even as the actual crime itself is missing.

The city at night, a sinister figure with an inscrutable countenance and an eccentric manner, a futile chase that leads through the darkened streets from the most fashionable parts of town to its most wretched slums, providing thereby a kind of street-level panorama of spatial economies and inequalities, an uneasy ending without moral resolution or the comfort of certitude - these tropes are the bare bones of a very particular kind of detective fiction, not the genteel Miss Marple world of tea at the vicarage, country house murders and the butler who dunnit, confessing dutifully when unmasked by the amateur sleuth on the final page, but the hard-boiled variety that was to flourish in sleazy and sordid 'means streets' of New York, San Francisco and Los Angeles, as penned by Dashiel Hamett, Raymond Chandler and Ross MacDonald. Poe's 'Man of the Crowd' is an x-ray not so much of the detective story per se, but of the crime thriller as noir. And it is to this term and this genre of crime fiction that I now turn.

Let us follow a trail, a trans-Atlantic one in fact, of our own: in the middle of the nineteenth century, the American writer Poe sets his tale 'The Man of the Crowd' in London and his two pioneering detective stories, featuring his amateur investigator, the ever insightful C. Auguste

\footnotetext{
${ }^{9}$ W. Benjamin, Selected Writings Vol. 4: 1938-40, Harvard UP, Cambridge MA, 2003, p. 27.
} 
Dupin, in Paris (the 'Murders in Rue Morgue' [1841], and the 'Mystery of Marie Roget' [1842-3] and 'The Purloined Letter' [1844-5] ); his work is read and celebrated by the definitive Parisian poet Charles Baudelaire. In the middle of the twentieth century, following liberation from Nazi occupation, Paris plays host to a tranche of new American films, thrillers and crime stories (among them, The Maltese Falcon, Laura, Murder My Sweet, Double Indemnity and The Woman in the Window) whose brooding mood, troubling atmosphere and ambiguous ethical content finds its ultimate designation and nomenclature in French: published in 1955, Raymond Borde and Étienne Chaumeton provide an overview of this new film genre and its reception in their study Panorma du Film Noir Américain. ${ }^{10}$ Born, like the detective story itself, in the interplay of American and French writers, noir is then re-exported back to the United States where it is adopted as the definitive signature of a particular literary and cinematic subject matter, style and sensibility. But our trail does not end there, far from it. It continues in all directions: noir or neo-noir is once more on the move. As a designation for a particular kind of gloomy, melancholy urban police procedural neo-noir has enjoyed a renaissance in Europe in recent years: today we can speak of Celtic noir (Ireland, Wales, Scotland), Tartan noir (Scotland), Nordic noir / Scandi-noir (Iceland, Norway, Sweden and Denmark, sometimes with financial backing from Germany). And such neo-noir is, of course, no stranger to East Asia. Noir as a shorthand and marketing device for a particular kind of text - literary, cinematic, or televisual - has conquered the globe; noir sans frontier.

Are we at the end? By no means, for, in the case of Nordic noir, there has been yet another return, a return of the return so to speak, as Scandinavian television series such as Bron/Broen (2011, 2013 and 2015) are reconfigured and remade in an American context as The Bridge (2013, 2014). From there the trail goes underground: Bron/Broen becomes the The Bridge and then is remade yet again, this time as The Tunnel $(2013,2016)$ featuring the Channel Tunnel as its transnational setting, in a British-French co-production. We have come full circle: we are back to where we began - London and Paris.

There are three points to be made here: the first is that concepts themselves travel transnationally, go walkabout, migrate, and then even return in altered guise. Concepts have a life of their own, well beyond those who conceive them, coin them. The flaneur is a case in

\footnotetext{
${ }^{10}$ In A. Silver and J. Ursini eds Film Noir Reader, Limelight Editions, New York, NY, 1996, pp. 17-25.
} 
point; so too is noir. Noir as a nomenclature, as a moniker, a signifier, is a transnational flaneur, and a highly marketable and profitable one too.

Secondly, popular cultural products, like the three series of Bron/Broen are not just translated via subtitles for international markets but transplanted wholesale as remakes into a wholly new locations and contexts. TV programmes are formats available for international export and become global phenomena. Concepts move hither and thither at the behest of branding agencies, markets and commercial interests; and so too do commercial TV formats: all this is exemplary of the transnational media cloning or rhizomic reproducibility typical of the 'global culture industry' identified by Scott Lash and Celia Lurie. ${ }^{11}$ For them, it is no longer products and goods that circulate as commodities but images, texts, ideas, rights and other intangible non-material forms. And I think one might see the negotiation of such global flows dramatized in miniature and parodied in the opening scenes of Bron/Broen and its offspring: all of these series start with the detectives from two different countries gathered on the eponymous structure (on the bridge, in the tunnel) haggling over the rights and responsibilities to investigate the crime that straddles their borders, to whom does the corpse, the crime scene, belong, who has prior claim, whose job is this?: one can see this as a satirical mirror image of the commercial carve up as TV producers from different countries hotly debate the copyright issues and franchizing deals of competing studios in a case of 'whose case is this'? To whom does this belong?

Thirdly, the actual detectives too, the literary characters, the onscreen protagonists, also come to be ad hoc transnational flaneurs and flaneuses, operating across borders, dispatched overseas, drafted in as extra outside expertise. This is a staple element in Scandinavian noir where it is seemingly routine for the principal detective figure to be sent abroad as part of some investigation, a sojourn elsewhere that offers, in addition to exotic locations and local colour, numerous possibilities for odd couple comedy as awkward hosts and reluctant guests, or reluctant hosts and awkward guests, negotiate conflicting responsibilities and unfamiliar policing procedures to crack the case and eventually part as budding buddies.

Written by two Marxist journalists (Mai Sjöwall and Per Wahlöö) and intended as a critical disclosure of the dark side of the Swedish liberal democratic welfare state system, the ten

\footnotetext{
${ }^{11}$ See S. Lash and C. Lurie, Global Culture Industry: The Mediation of Things. Polity Press, Cambridg, UK, 2007..
} 
Stockholm-set Martin Beck stories published between 1965 and 1975 were the trailblazers of Nordic noir and set the pattern: Martin Beck's second outing in The Man Who Went Up in Smoke (1966) sees him sent to Budapest to find a journalist who has failed to return from Hungary. The second and third of Henning Mankell's international best-selling series involving the lugubrious detective Kurt Wallender requires him to leave his Swedish hometown of Ystad to pursue investigations in Estonia (Dogs of Riga, 1992) and then South Africa (The White Lioness, 1993). And, in an unorthodox and audacious gambit, the Norwegian writer Jo Nesbø sets the first two of his Harry Hole series abroad: The Bat (1997) in Sydney, Australia, and The Cockroaches (1998) in Thailand. It is not until the third book, The Redbreast (2000) that the hometown 'Oslo stories' actually begin.

It is with Bron / Broen that the Scandinavian detective as transnational flaneur finds it apotheosis: why?, because the two detectives involved - the Swedish officer Saga Noren and the Danish detective Martin Rohde (replaced in series 3 by Henrik Sabroe) - are not occasional visitors to foreign climes, investigative tourists, but rather motorized transnational commuters who spend their time criss-crossing the eponymous transnational Øresund Bridge connecting the cities of Malmo and Copenhagen. As such, they are, then, daily car-bound flaneuse and flaneur both within cities and between cities in neighbouring countries. And so too are Sonya Cross (an appropriate name for one who passes over bridges) of the El Paso PD and Marco Ruiz of the Chihuahua State Police, the protagonists of the two American remakes, The Bridge, set on the Texas-Mexico border and focused on the perennially gridlocked Bridge of the Americas connecting El Paso and Juarez.

Significantly, in neither case, North American and Scandinavian, does this transnational police-work involve the seemingly seamless traversing and transcending of borders, harmonious co-operation and collaboration, homeliness amidst the unhomely. Rather, these figures encounter and negotiate a plethora of difficulties and dangers in which gender stereotypes and national prejudices are played out - sometimes to comic effect in the portrayal of Scandinavian clichés (Swedish uptightness, Danish breakfast rolls), more often with sinister undercurrents (the corruption of Mexican authorities, the violence of the streets in Juarez). Unlike the utopian transnational flaneur, these figures do not move at ease, at will, through these contrasting worlds, not even in the vehicular refuge of their cars. Indeed, whether aimlessly circling the deserted nocturnal motorways and intersections of Malmo / Copenhagen or cruising through the desert / deserted outskirts and ruinous Tex-Max streetscapes of El Paso / Juarez, these are contrasting but equally disquieting visions of the 
contemporary city and, tellingly, of those whose job it is to move in and through them in pursuit of the fugitive "type and genius of deep crime", as Poe puts it in 'The Man of the Crowd', the uncanny, unnerving figure who has himself adopted trans-nationalism, the serial killer sans frontiers.

If the transnational flaneur dwells comfortably anywhere and everywhere, and especially in those various ambiguous and ambivalent urban loci that Benjamin would deem as 'thresholds' (Schwellen) and / or 'passages' (Passagen) and Kracauer would designate under the rubric of 'in-between spaces' (Zwischenräume), ${ }^{12}$ sites characterized by their very indeterminacy and obscurity, then the eponymous edifice of the bridge is precisely and quintessentially a domicile for the "spiritually shelterless". ${ }^{13}$ Bron $\mid$ Broen and The Bridge presents us with transnational detectives as four-wheeled flaneurs, as restless urban nomads, who are seemingly only truly at home on the bridge itself. Seemingly. The object of frequent depiction and repeated traversal the two bridges - the Øresund Bridge and the Bridge of the Americas - are themselves indeed visual leitmotivs: but less in terms of that commonplace symbol, as Georg Simmel ${ }^{14}$ noted over century ago, of connectivity and communication, of amicable co-operation and co-existence, of legal and legitimate transit (unlike the tunnel), indeed, of the transnational itself, of utopian possibility and harmonious potentiality; and much more as an exemplary functional and liminal structure, spanning the void, existing neither here nor there, the architecture par excellence of transit and transition, a construction of passage unremarkably experienced not so much en passant as en traversant, a means but not an endpoint, a nobody's land betwixt and between, a nowhere linking two somewhere, as a veritable 'non-place' to use Marc Augé's term for all such characteristically passed through and passed over sites of contemporary supermodernity. Here, the bridge is as inscrutable, as illegible, as the Pharaoh's column. It does not permit itself to be read - not because the script carved upon it is undecipherable but because it simply has nothing to say to those who speed across it.

The suspension bridge is where the flaneur-as-detective finds himself / herself in motion yet suspended, returning time and time again, crossing over and over again. It keeps him, her, us

\footnotetext{
${ }^{12}$ See S. Kracauer, Strassen in Berlin und Anderswo, Das Arsenal Verlag, Berlin,1987.

${ }^{13}$ S. Kracauer, The Salaried Masses. Duty and Distraction in Weimar Germany. Verso, London: Verso, 1998, p. 88.

${ }^{14}$ See his essay 'Bridge and Door' in D. Frisby and M. Featherstone eds, Simmel on Culture. Selected Writings, Sage, London, 1997, pp. 170-3.
} 
in suspense. It connects not just here and there, but also the beginning and the end. The bridge serves as both starting and finishing point of the actual narrative: we have been going in circles the whole time, getting nowhere. The drama opens with the corpse(s), the dissected bodies of the two victims laid out exactly on the borderline; it concludes in the company of the cool calculating killer himself on a train brought to a standstill at the central span by means of the emergency brake. The bridge has murder and mutilation at one end, so to speak, and the triumphant taunts of the killer at the other. Homicide and hopelessness: they are both, as the old song goes, 'stuck in the middle with you'. The detective, not the criminal, is the one who is caught, trapped, left inconsolable. If, as Kracauer observes, "spatial images are

the dreams of society" 15 then in this instance, the bridge is its nightmare. Not even a flaneur could feel at ease here; nothing can live here, survive here, but somehow the detective must endure. The bridge is not a home, but a haunt: both a site of mourning that one cannot but return to incessantly, and a figure which one cannot ever escape. This is noir after all, noir sans frontiers. And, as the song tells us: "everything goes back to the beginning .."

Dr Graeme Gilloch is a Reader in the Department of Sociology, Lancaster University, UK.

\section{References}

Baudelaire, C. The Painter of Modern Life and Other Essays. Da Capo Press, New York, NY, 1964/1986.

Benjamin, W. Selected Writings Vol. 1: 1913-26, Harvard UP, Cambridge MA, 1996

Benjamin, W. The Arcades Project, Harvard UP, Cambridge MA, 1999.

Benjamin, W. Selected Writings Vol. 4: 1938-40, Harvard UP, Cambridge, 2003.

Boltanski, L. Mysteries and Conspiracies. Detective Stories, Spy Novels and the Making of Modern Society, Polity Press, Cambridge, 2014.

\footnotetext{
${ }^{15}$ Strassen in Berlin und Anderswo, 1987, p. 52.
} 
Frisby D. and M. Featherstone eds. Simmel on Culture. Selected Writings, Sage, London, 1997.

Hessel, F. Walking in Berlin. A Flaneur in the Capital, Scribe Editions, Melbourne / London, 2016.

Kracauer, S. Strassen in Berlin und Anderswo, Das Arsenal Verlag, Berlin, 1987.

Kracauer, S. The Salaried Masses. Duty and Distraction in Weimar Germany, Verso, London, 1998.

Lash, S. and C. Lurie (2007) Global Culture Industry: The Mediation of Things. Polity Press. Cambridge, UK, 2007.

Mankell, H. Dogs of Riga, Vintage, London, 1992/2012.

Mankell, H. The White Lioness, Vintage, London, 1993/2009.

Nesbø, J. The Bat, Vintage, London, 1997/2013.

Nesbø, J. Cockroaches, Vintage, London, 1998/2014.

Nesbø, J. Redbreast, Vintage, London, 2000/2009.

Poe, E. A. The Portable Edgar Allan Poe, Penguin, London, 2006.

Silver, A. and J. Ursini eds. Film Noir Reader, Limelight Editions, New York, NY, 1996.

Sjöwall, M. and P. Wahlöö, The Man Who Went up in Smoke, Fourth Estate, London, $1966 / 2011$. 